\title{
HUBUNGAN RESPONSE TIME DENGAN TINGKAT KECEMASAN KELUARGA PASIEN DI INSTALASI GAWAT DARURAT RSUD AMBARAWA
}

\author{
Maria Agustina Ermi T.S, Ria Enes Aprilianti, Probowatie Tjondronegoro \\ Stikes St. Elisabeth Semarang Jln. Kawi No. 11, Semarang, (024)8412729 \\ Email : ermi.trisulistiyowati@gmail.com
}

\begin{abstract}
ABSTRAK
Response time adalah kecepatan penanganan pasien yang dihitung sejak pasien tiba di pintu instalasi gawat darurat ( IGD) sampai dilakukan penanganan dengan standar waktu pelayanan yang diperlukan paling lama 3 (tiga) menit setelah sampai di IGD. Kecemasan keluarga pasien adalah pengalaman subjektif yang tidak menyenangkan mengenai kekhawatiran atau ketegangan berupa perasaan cemas dan emosi yang dialami keluarga ketika mengantar pasien ke IGD. Penelitian bertujuan untuk mengetahui hubungan response time dengan tingkat kecemasan keluarga pasien di IGD. Desain penelitianyang digunakan adalah deskriptif analitik dengan pendekatan Cross sectional. Sampel penelitian adalah keluarga yang datang ke IGD sebanyak 93 orang yang telah memenuhi kriteria inklusi dan eksklusi. Pengambilan sampel menggunakan teknik purposive sampling. Pengolahan data menggunakan uji Kolmogorov smirnov. Hasil penelitian menunjukkan 90 responden (96,8\%) mendapatkan response time baik dan 3 responden $(3,2 \%)$ mendapatkan response time kurang baik. Keluarga pasien tidak cemas 58 orang $(62,4 \%)$, cemas ringan 23 orang $(24,7 \%)$, cemas sedang 11 orang $(11,8 \%)$, cemas berat 1 orang $(1,1 \%)$. Analisis uji Kolmogorov smirnov menunjukkan $p$-value 0,018 . Terdapat hubungan response time dengan tingkat kecemasan keluarga pasien
\end{abstract}

Kata kunci : response time; kecemasan; keluarga pasien

\begin{abstract}
Response time is the speed of handling patients calculated when the patients arrived at emergency door until get treatment with care time standard need's maximum 3 minutes after arrive in emergency room. Anxiety of patient's families is an unpleasant subjective experience about worries or tension in the form of feelings of anxiety and emotions experienced by family when they delivered patient's to emergency room. This research was aimed to know relation of response time with anxiety level's of patient's families in emergency room. The research design used was descriptive analytic with the Cross section approach. Sample in this research was the family whose arrive in emergency room totally 93 peoples who have met the inclusion and exclusion criteria. Method of sampling used purposive sampling. The statistical test used kolmogorov smirnov test. The results showed 90 respondent's $(96,8 \%)$ get a good response time, 3 respondent's $(3,2 \%)$ get not good response time. Patients families mostly not had anxiety 58 people's $(62,4 \%)$, mild anxiety 23 people's $(24,7 \%)$, medium anxiety 11 people's $(11,8 \%)$, heavy anxiety 1 people $(1,1 \%)$. Analysis of Kolmogorov smirnov test showed $p$ value 0,018 . There is have relation of response time with anxiety level's of patient's families
\end{abstract}

Keywords : response time; anxiety; patient's families 


\section{LATAR BELAKANG}

Rumah sakit merupakan institusi pelayanan kesehatan yang melaksanakan pelayanan kesehatan perorangan meliputi pelayanan rawat inap, rawat jalan, dan gawat darurat (Kemenkes $\mathrm{RI}, 2008)$. Pelayanan gawat darurat di rumah sakit dilakukan di Instalasi Gawat Darurat (IGD). IGD merupakan gerbang utama jalan masuknya pasien gawat darurat (Musliha,2010). Filosofi dalam penanganan gawat darurat yaitu Time Saving is Life Saving artinya seluruh tindakan yang dilakukan pada saat kondisi gawat darurat harus benar-benar efektif dan efisien. Hal ini mengingatkan bahwa pasien dapat kehilangan nyawa hanya dalam hitungan menit saja. Berhenti nafas selama 2-3 menit pada manusia dapat menyebabkan kematian yang fatal (Sutawijaya,2009).

Indikator mutu pelayanan rumah sakit pada bagian IGD yaitu waktu tanggap atau response time. Response time di IGD merupakan waktu yang dibutuhkan dari saat pasien tiba di depan pintu rumah sakit sampai mendapat respon dari petugas instalasi gawat darurat, dengan standar waktu $\leq 5$ menit pasien terlayani setelah tiba di IGD (Kemenkes RI,2008). Waktu tanggap dikatakan tepat waktu atau tidak terlambat apabila waktu yang diperlukan tidak melebihi waktu rata-rata standar yang ada.

Pasien yang dibawa ke IGD umumnya merupakan pasien gawat darurat yang membutuhkan tindakan yang cepat dan tepat. Gawat merupakan suatu keadaan mengancam nyawa, sedangkan darurat adalah perlu mendapatkan penanganan atau tindakan dengan segera untuk menghilangkan ancaman nyawa (Musliha,2010). Kondisi pasien yang dirawat di IGD dapat menimbulkan kecemasan pada keluarganya. Kecemasan keluarga ditandai dengan sering bertanya, gelisah, mondar-mandir dan berfikir bahwa firasat buruk akan terjadi (Barbara,2010).

Penelitian yang dilakukan Listriani tentang gambaran tingkat kecemasan keluarga pasien di ruang instalasi gawat darurat RSUP Dr Wahidin Sudirohusodo Makassar menunjukkan bahwa mayoritas responden mengalami kecemasan $69.9 \%$, sedangkan yang tidak mengalami kecemasan adalah sebanyak $30.1 \%$ (Listriani ,2013). Penelitian yang dilakukan oleh Tumbuan tentang hubungan response time dengan tingkat kecemasan pasien kategori triase kuning di IGD RSU GMIM Kalooran Amurang menunjukkan bahwa terdapat hubungan yang signifikan antara response time perawat dengan tingkat kecemasan pasien kategori triase kuning (Tumbuan,2015).

Penelitian yang dilakukan oleh Maatilu tentang faktor-faktor yang berhubungan dengan response time perawat pada penanganan pasien gawat darurat di IGD RSUP Prof Dr. R. D. Kandou Manado hasil menunjukkan bahwa response time perawat dalam penanganan kasus gawat darurat rata-rata $>5$ menit (Maatilu ,2014). Hasil penelitian di IGD Rs. Umum Dr.Soedirman Kebumen menunjukkan response time perawat dalam tindakan keperawatan $25 \%$ dalam kategori lambat (Bangkit,2016).

Fenomena yang terjadi menunjukkan belum terpenuhinya standar response time (waktu tanggap) di IGD, sedangkan response time sendiri pada penelitian sebelumnya menunjukkan adanya hubungan dengan kecemasan pasien.

\section{METODE}

Desain penelitian yang digunakan adalah deskriptif analitik dengan pendekatan cross sectional. Populasi dalam penelitian ini adalah keluarga pasien yang mengantar pasien di IGD RSUD Ambarawa sebanyak 93 orang. Sampel diambil dengan menggunakan metode purposive sampling. Data Dianalisa dengan uji KolmogorovSmirnov.

\section{HASIL}

Berdasarkan tabel 1 menunjukkan bahwa ratarata response time 27 detik, response time paling cepat yaitu 0 detik dan response time paling lambat yaitu 3 menit 7 detik. Dari 93 responden, ada 90 responden $(96,8 \%)$ mendapatkan response time baik. 
Ermi, et al,. Hubungan Response Time Dengan Tingkat Kecemasan Keluarga Pasien ....

SJKP, Vol. 6, No. 1, Juni 2019, 1-7.

Tabel 1. Response time

\begin{tabular}{cccc}
\hline $\begin{array}{c}\text { Response } \\
\text { Time }\end{array}$ & Jumlah & $\%$ & $\begin{array}{c}\text { Mean } \\
\text { (Min-Max) }\end{array}$ \\
\hline Baik & 90 & 96,8 & \\
Kurang baik & 3 & 3,2 & $\begin{array}{c}0.27(0.00- \\
3.07)\end{array}$ \\
\cline { 1 - 3 } Total & 93 & 100 & \\
\hline
\end{tabular}

Tabel 2 menunjukkan responden paling banyak pada responden adalah tidak cemas dengan jumlah 58 responden (62.4\%), dan paling sedikit mengalami cemas berat sebanyak 1 responden (1.1\%).
Tabel 2. Tingkat Kecemasan Keluarga Pasien

\begin{tabular}{lcc}
\hline $\begin{array}{c}\text { Tingkat } \\
\text { Kecemasan }\end{array}$ & Frekuensi (n) & $\begin{array}{c}\text { Persentase } \\
(\%)\end{array}$ \\
\hline Tidak cemas & 58 & 62.4 \\
Cemas ringan & 23 & 24.7 \\
Cemas sedang & 11 & 11.8 \\
Cemas berat & 1 & 1.1 \\
\hline \multicolumn{1}{c}{ Total } & 93 & 100 \\
\hline
\end{tabular}

Tabel 3. Hubungan Response Time dengan Tingkat Kecemasan Keluarga Pasien

\begin{tabular}{cccccccc}
\hline \multirow{3}{*}{ Response Time } & \multicolumn{3}{c}{ Tingkat Kecemasan $\mathbf{n}(\%)$} & \multirow{2}{*}{ Jumlah } & P value \\
\cline { 2 - 5 } & Tidak cemas & Ringan & Sedang & Berat & & \multirow{2}{*}{0,018} \\
Baik & 58 & 23 & 9 & 0 & 90 & \\
& $(62,4)$ & $(24,7)$ & $(9,7)$ & $(0)$ & $(96,8)$ & \\
Kurang baik & 0 & 0 & 2 & 1 & 3 & \\
& $(0)$ & $(0)$ & $(2,2)$ & $(1,1)$ & $(3,2)$ & \\
Total & 58 & 23 & 11 & 1 & 93 & \\
& $(62,4)$ & $(24,7)$ & $(11,8)$ & $(1,1)$ & $(100)$ \\
\hline
\end{tabular}

*Uji kolmogorov smirnov

Hasil di atas menunjukkan hubungan response time dengan tingkat kecemasan keluarga pasien. Hasil uji kolmogorov smirnov menunjukkan $p$ value $0,018(<0,05)$ yang berarti $\mathrm{H}_{0}$ ditolak dan $\mathrm{H}_{1}$ diterima yang artinya ada hubungan response time dengan tingkat kecemasan keluarga pasien di IGD.

\section{PEMBAHASAN}

Response time adalah kecepatan penanganan pasien yang dihitung sejak pasien tiba di pintu IGD sampai dilakukan penanganan. Berdasarkan Rencana Manajemen Mutu (RMM) di IGD RSUD Ambarawa, standar response time triase yang di perlukan maksimal 3 (tiga) menit. Hasil penelitian menunjukkan bahwa rata-rata response time yaitu 27 detik, response time paling cepat yaitu 0 detik dan response time paling lambat yaitu 3 menit 7 detik. Dari 93 responden, 90 responden $(96,8 \%)$ mendapatkan response time baik dan 3 responden $(4.3 \%)$ mendapatkan response time kurang baik. Terjadinya keterlambatan dalam pelayanan response time di IGD disebabkan karena tidak tersedianya dokter dan perawat di meja triase pada saat jumlah pasien yang datang banyak, hal ini membuat pasien baru yang datang tidak tertangani dengan cepat.

Pasien yang masuk ke IGD memerlukan pelayanan yang cepat, tepat dan cermat untuk mencegah kematian dan kecacatan. Pelayanan pasien gawat darurat memegang peranan yang sangat penting (Time saving is life saving), waktu adalah nyawa. Respon time di IGD dapat mempengaruhi kelangsungan hidup pasien (Sutawijaya,2009).

Hasil penelitian tingkat kecemasan keluarga pasien didapatkan data sebanyak 58 orang $(62,4 \%)$ tidak mengalami kecemasan, 23 orang $(24,7 \%)$ mengalami cemas ringan, 11 orang $(11,8 \%)$ mengalami cemas sedang, dan 1 orang $(1,1 \%)$ mengalami cemas berat. Kecemasan merupakan pengalaman subjektif yang tidak menyenangkan mengenai kekhawatiran atau 
ketegangan berupa perasaan cemas dan emosi yang dialami sesorang (Ghufron,2010).

Sebagian besar reponden tidak menunjukkan tanda kecemasan seperti jantung berdebar - debar, gemetar, mual, telapak tangan berkeringat, gugup,dan mondar-mandir. Pada penelitian ini responden yang tidak cemas semuanya mendapatkan response time yang baik. Responden yang mengalami cemas dapat disebabkan karena kondisi kesehatan yang dialami oleh anggota keluarganya yang sedang sakit.

Kecemasan pada keluarga khususnya yang mempunyai anggota keluarga yang sakit merupakan bentuk adanya gangguan emosional individu yang tidak adekuat. Kecemasan umumnya dialami oleh keluarga pasien terutama ibu, dimana adanya ikatan batin yang kuat dan akhirnya akan memunculkan reaksi emosional (Stuart,2006).

Penelitian menunjukkan bahwa ada hubungan response time dengan tingkat kecemasan keluarga pasien di IGD dengan signifikansi $0,018 \quad(<0,05)$. Pada penelitian ini, responden yang mendapatkan response time kurang baik semuanya mengalami kecemasan, sedangkan yang mendapatkan response time baik, sebagian besar tidak mengalami cemas. Semakin cepat response time yang diterima pasien, maka keluarga pasien semakin tidak cemas.

Menunggu dapat membuat keluarga pasien merasa cemas karena kondisi anggota keluarganya yang dalam kondisi sakit memerlukan pertolongan segera dan dapat mengancam nyawa. Kecepatan dalam memberikan pelayanan dapat mencegah terjadinya kondisi yang buruk pada pasien. Selain itu, keluarga tidak menunggu lama untuk mendapatkan penanganan sehingga kecemasan keluarga pasien akan berkurang.

\section{KESIMPULAN DAN SARAN}

Sebanyak 90 responden $(96,8 \%)$ mendapatkan response time baik, dan 3 responden $(3,2 \%)$ mendapatkan response time kurang baik. Sebanyak 58 orang $(62,4 \%)$ tidak mengalami kecemasan, 23 orang $(24,7 \%)$ mengalami cemas ringan, 11 orang $(11,8 \%)$ mengalami cemas sedang, 1 orang $(1,1 \%)$ mengalami cemas berat, dan tidak ada yang panik $(0 \%)$. Hasil Uji kolmogorov smirnov didapatkan $p$ value 0,018 ( $p$ $<0,05)$ ada hubungan response time dengan tingkat kecemasan keluarga pasien. Rumah sakit memberikan pelayanan gawat darurat dengan response time sesuai standar yang telah ditentukan.

\section{REFERENSI}

Bangkit Faiq et al.(Hubungan Response Time Perawat dengan Tingkat Kecemasan Pasien Kategori Triase Kuning di Instalasi Gawat Darurat Rumah Sakit Umum Daerah dr. Soedirman Kebumen. Available from:http://elib.stikesmuhgombong.ac.id/114

Barbara et al. (2010). Buku Ajar Fundamental Keperawatan. Jakarta: Penerbit buku kedokteran EGC

Ghufron et al. (2010). Teori-Teori Psikologis.Yogyakarta : Ar Rus Media

Kementerian Kesehatan Republik Indonesia.(2008). Standar Pelayanan Minimal Rumah Sakit.Jakarta: Kemenkes RI

Kementerian Kesehatan RI.(2009). Undang-Undang RI. Nomor 44 Tahun 2009 tentang Rumah Sakit. Jakarta: Kemenkes RI

Kementerian Kesehatan. (2009). Kepmenkes RI Nomor 856/Menkes/SK/IX/2009 Tentang Standar Instalasi Gawat Darurat (IGD) Rumah Sakit.Jakarta:Kemenkes RI

Listriani. (2013).Gambaran Tingkat Kecemasan Keluarga pasien di ruang Instalasi Gawat Garurat RSUP Dr Wahidin Sudirohusodo Makassar. Available from: http://repository.unhas.ac.id:4001/digilib/files/disk 1/21/--irdianiwij-1020-1-13-irdia-i.pdf

Maatilu.(2014). Faktor-faktor yang berhubungan dengan response time Perawat Pada Penanganan Pasien Gawat Darurat Di IGD RSUP Prof.DR. R.D. Kandou Manado. Fakultas Kedokteran Universitas Sam Ratulangi :Jurnal Keperawatan. 
Ermi, et al,. Hubungan Response Time Dengan Tingkat Kecemasan Keluarga Pasien .... SJKP, Vol. 6, No. 1, Juni 2019, 1-7.

Musliha.(2010). Keperawatan Gawat Darurat.Yogyakarta: Nuha Medika

Stuart.(2006). Buku Saku Keperawatan Jiwa.Jakarta: EGC

Sutawijaya, RB.(2009).Gawat Darurat.Yogyakarta: Aulia Publishing 